American Journal of Applied Sciences 8 (3): 246-253, 2011

ISSN 1546-9239

(C) 2010 Science Publications

\title{
Evaluating the Green Suppliers of the Printed Circuit Board Factories Base on the Fuzzy Analytic Hierarchy Process and Vlsekriterijumska Optimizacija I Kompromisno Resenje
}

\author{
${ }^{1}$ Jun-Yuan Kuo, ${ }^{2}$ Ben-Chang Shia, ${ }^{3}$ Yun-Chin Chen and ${ }^{1}$ Jou-Ying Ho \\ ${ }^{1}$ Department of International Business, Kainan University, \\ Taoyuan County, 338, ROC, Taiwan \\ ${ }^{2}$ Department of Statistics and Information Science, \\ Fu Jen Catholic University, Taipei Hsien, 24205, ROC, Taiwan \\ ${ }^{3}$ Department of Business Administration, De Lin Institute of Technology \\ No.1, Ln. 380, Qingyun Rd, New Taipei City 236, ROC, Taiwan
}

\begin{abstract}
Problem statement: The "Energy Policy for Europe, EPE" and three environmental directives, proposed by the European Union (EU) in 2007, are stricter than those self-restrained by the enterprises. For this reason, the enterprises have to shortly improve their products for meeting with the strict requests setup by the EU. Consequently, it becomes even more important that the manufacturers evaluate the green suppliers. Approach: Through arranging the index literatures for evaluating the green suppliers and applying the Fuzzy Analytic Hierarchy Process (FAHP) and the Vlsekriterijumska Optimizacija I Kompromisno Resenje (VIKOR) in this study, it will be discussed that the Printed Circuit Board (PCB) company in this case study evaluates and assesses the performances of three types of green suppliers (the suppliers of processing machine tools, the suppliers of raw materials and the suppliers of maintenance spare parts). The weight of performance indicators was derived by FAHP method, which were input to the VIKOR method for evaluate the performance of three types of green suppliers. Results: The research results, which the company in this case study assessed at the suppliers of the equipment machine tools, the raw materials and the spare parts, show that the satisfaction of the suppliers of raw materials is superior to the suppliers of equipment machine tools and even better than that of the suppliers of spare parts. Conclusion/Recommendations: The feasibility green supplier of performance evaluation method was presented through a real scenario, which can help the PCB procurements make objectively and distinguish the disadvantages and advantages of the green suppliers.
\end{abstract}

Key words: Green suppliers, hierarchy process, Printed Circuit Board (PCB), equipment machine tools, fuzzy logic, evaluation indices, research method, environment-protection directives, European Union (EU)

\section{INTRODUCTION}

The object of environment protection is an important trend to the future industries. The worldwide governments and international enterprises also keep focusing on the issues of the environment protection, green production, green procurement and recycle.

All companies must keep improving their procedures of production, procurement and transportation for gradually decreasing the volume of carbon emission and achieving the goals and requests of environment protection. In a past decade, the EU has also issued the three environment-protection directives (European, 2007) and has requested the manufacturers to use the WEEE recovery-and-recycle products to the utmost for designing the green products. Additionally, the EU has asked to minimally use Restriction of Hazardous Substances (RoHs) hazardous materials and limit the emissions of greenhouse gases to the lowest level (European, 2007).

To the general PCB industries, the three environment-protection directives issued by the $\mathrm{EU}$ totally cover the substrate materials selected during the design period, the chemical materials used in the manufacturing processes and the final product processes including the quality inspections, packing and transportation to the customers. In other words, it should be seriously considered if the products agree

Corresponding Author: Jun-Yuan Kuo, Department of International Business, Kainan University, Taoyuan County, Taiwan 338, ROC, Taiwan 
with the EU's standards at the beginning of design. Therefore, the EU's three environment-protection directives do greatly impact on the PCB industries. The factory owners must obey the coverage of the EU's regulations and make all procedures of product procurement, processing, transportation and so on to meet with the national carbon-emission standards in the Europe.

For above reasons, the PCB factory owners must follow the EU's environment-protection regulations from the evaluation of the green suppliers to the procedures of manufacturing, transportation and recovery. Specifically, to evaluate and select the green suppliers is a quite important and far-reaching issue, which impacts not just on the environment-protection achievements of the enterprises and their products. The unsuitable green suppliers will also cause the goodwill humiliation and the cost lost of the enterprises.

Because of the keen competition on evaluations between global markets, the excellent suppliers will bring huge benefits to the manufacturers in the PCB industries. In these years, with the advancement of the environment-protection consciousness and for meeting with the requests of environment-protection regulations, the problem that manufacturers choose the green suppliers is becoming remarkable. In consequence, the experts and scholars gradually pay attention to this subject.

According the coverage of the EU's three environment protection directives to the processes of the PCB industries (European, 2007), all WEEE's products from manufacturing processes to delivery to customers should be recovered and regenerated. RoHS directive regulates that the hazard content should be lower than the level of dissolving toxicity in the overall manufacturing processes and delivery to the customers. Nevertheless, the EuP directive requires that the recovery and the minimal volume of total carbon emission should be considered at the beginning of design.

The green procurements and processes, therefore, have evolved to be a forthcoming important trend. To evaluate the green suppliers is one of the more and more emphasized topics to the managers. Lee et al. (2009) proposed selection model of green suppliers for the hi-tech industries. Employing the Delphi method, Analytic Hierarchy Process (AHP), Fuzzy set theory and Fuzzy Delphi method, manufacturers can assess and select the most suitable green suppliers for cooperation. (Xinxing et al., 2009) presented the suppliers with supply chain of agile selection: a kind of information processing model and instruction, which uses the method of Radial Basis Function (RBF) artificial neural network on the business trades including the electric appliances, equipment manufactures and so on in China. (Gheidar et al., 2009) submitted to employ a mathematical model to solve the problem of total cost of supply chain and adopt the mixed integer nonlinear planning to construct the problems of supplier selection, through selecting suppliers to optimize the benefit of the integral supply chain and buyers' benefit. Kuo et al. (2010) used the integrated method of the enterprise artificial neural network and multi-attribute decisions to analyze the selection of green suppliers. (Punniyamoorthy et al., 2011) also adopted the structure equation model and fuzzy logic to choose the supplier strategy models.

Many researchers have focused the problems in the PCB industries and solve the problems by research methods in their investigations (Rahmat et al., 2010; Misran et al., 2008; Kumar et al., 2009; Daut et al., 2006). The concept of evaluation index also has extensively applied by numerous researches (Nader and Mehdizadeh, 2010; Liu, 2005). There are also many research discuss about the environment protection and the EU's information (Hoffmann and Hoffmann, 2007; Athanasios et al., 2010).

Integrating above literatures, there is fewer literatures having ever discussed the satisfaction to evaluate the green suppliers in the PCB industries and the satisfaction assessment of the suppliers of processing machine tools, raw materials and maintenance spare parts. Therefore, through arranging the index literatures for evaluating the green suppliers and applying the Fuzzy Analytic Hierarchy Process (FAHP) and the Vlsekriterijumska Optimizacija I Kompromisno Resenje (VIKOR) to conduct the analyses, hopefully, this study will provide the PCB factory owners with a reference direction to evaluate the green suppliers. In addition, this study may be treated as a reference direction in conducting green processes and procurements for the company in this case study.

\section{MATERIALS AND METHODS}

This study applied the FAHP and VIKOR concepts to help procurements to make proper decisions in evaluating Suppliers performance. This research consists of three stages, including (1) the green supplier performance indicators identification stage, (2) the green supplier performance evaluation stage and (3) comparison and analysis stage. The Fig. 1 shows the structure in this research.

The AHP is the research foundation of FAHP, the FAHP is a famous research method for analyzing problems and finding out the important indices and weights. Many researchers has applied AHP and FAHP to solve their problems in their investigations (Cheong 
et al., 2008; Lotfi et al., 2009; Liu, 2005; Ahmed et al., 2009; Bovornsethanant and Wongwises, 2010.) The VIKOR is one of research methods for sorting plenty of projects. (Wu et al., 2009) proposed the Fuzzy Multiple Criteria Decision Making (FMCDM) and assessed the achievements of banks on the basis of the concept of balanced scorecard. $\mathrm{Wu}$ used the FAHP to calculate the weights of evaluation indices and later respectively used the SAW, TOPSIS and VIKOR to grade the achievements of banks. Also, the results will be analyzed and compared (Wu et al., 2009).Besides, according to the optimal solution by the VIKOR again, the evaluations and analyses of suppliers are conducted and the instruction and explanation are presented.

Green supplier performance indicators identification stage: In this stage, the data information of the Supply process was collected and the literature on the performance indicators for procurements was reviewed. This study is for conducting the research on evaluating and selecting the green suppliers for the PCB industries.

Based on the Hierarchy structure of the evaluation indices of the green suppliers proposed by (Lee et al., 2009) as a research foundation, the suitable aspects and indices are picked up for designing the questionnaire contents to discuss with subject company managers. Further, the FAHP is applied to implement pair-wise comparison.

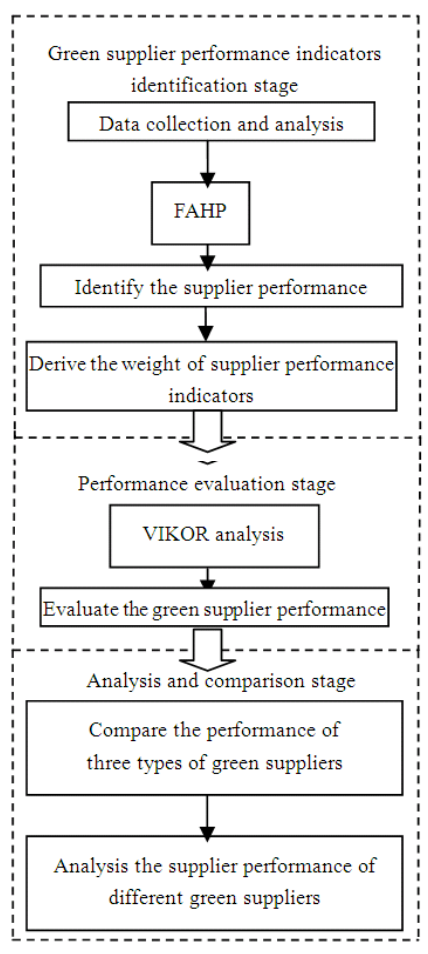

Fig. 1: Structure of this study
There is no human subjective determination involved in the conventional Analytic Hierarchy Process. The selection and preference have a great influence on policymakers. Buckley (1985) used this evolution algorithm to calculate the weights and trapezoidal fuzzy number which can even accurately compute the values most close to those filled by experts and scholars.

Thus, the triangular fuzzy number is used to calculate the weights of the fuzzy interval to the evaluation indices of suppliers. The calculation steps of FAHP are listed as below (Buckley, 1985).

Construct fuzzy pair-wise comparison matrix B and compare the weight of each rule and check the uniformity of matrix $\tilde{B}$ :

$$
\tilde{\mathrm{B}}=\left[\begin{array}{cccc}
1 & \tilde{\mathrm{b}}_{12} & \cdots & \tilde{\mathrm{b}}_{1 \mathrm{n}} \\
\tilde{\mathrm{b}}_{21} & 1 & \cdots & \tilde{\mathrm{b}}_{2 \mathrm{n}} \\
\vdots & \vdots & \ddots & \vdots \\
\tilde{\mathrm{b}}_{\mathrm{n} 1} & \tilde{\mathrm{b}}_{\mathrm{n} 2} & \cdots & 1
\end{array}\right]=\left[\begin{array}{cccc}
1 & \tilde{\mathrm{b}}_{12} & \cdots & \tilde{\mathrm{b}}_{1 \mathrm{n}} \\
1 / \tilde{\mathrm{b}}_{12} & 1 & \cdots & \tilde{\mathrm{b}}_{2 \mathrm{n}} \\
\vdots & \vdots & \ddots & \vdots \\
1 / \tilde{b}_{1 \mathrm{n}} & 1 / \tilde{\mathrm{b}}_{2 \mathrm{n}} & \cdots & 1
\end{array}\right]
$$

Calculating the triangular fuzzy numbers of: Triangular fuzzy numbers represented by $\tilde{B}=(L, M, U)$, where $U$ and $L$ are the possible upper and lower boundaries of the fuzziness data respectively.

Use the fuzzy geometric means $\tilde{\mathrm{r}}_{\mathrm{i}}$ to compute the fuzzy weights $\tilde{\mathrm{w}}_{\mathrm{i}}$ of the positive reciprocal matrix and use themethod of Center Of Area (COA) proposed by Opricovic and Tzeng (2003). Employ the BNP (Best Nonfuzzy Performance Value) to solve defuzzification (Sun et al., 2009; Wu et al., 2009):

$$
\begin{aligned}
& \tilde{\mathrm{r}}_{\mathrm{i}}=\left(\tilde{\mathrm{b}}_{\mathrm{i} 1} \otimes \tilde{\mathrm{b}}_{\mathrm{i} 2} \otimes \cdots \otimes \tilde{\mathrm{b}}_{\mathrm{in}}\right)^{1 / \mathrm{n}} \\
& \tilde{\mathrm{w}}_{\mathrm{i}}=\tilde{\mathrm{r}}_{\mathrm{i}} \otimes\left(\tilde{\mathrm{r}}_{1} \oplus \cdots \oplus \tilde{\mathrm{r}}_{\mathrm{m}}\right)^{-1} \\
& \mathrm{BNP}_{\mathrm{i}}=\left[\left(\mathrm{UR}_{\mathrm{i}}-\mathrm{LR}_{\mathrm{i}}\right)+\left(\mathrm{MR}_{\mathrm{i}}-\mathrm{LR}_{\mathrm{i}}\right)\right] / 3+\mathrm{LR}_{\mathrm{i}}, \forall \mathrm{i}
\end{aligned}
$$

Normalize the fuzzy weight matrices $\mathrm{NW}_{\mathrm{i}}$ and analyze and compare them (Wu et al., 2009):

$$
\mathrm{NW}_{\mathrm{i}}=\mathrm{BNP}_{\mathrm{i}} / \sum_{\mathrm{i}=1}^{\mathrm{n}} \mathrm{BNP}_{\mathrm{i}}
$$

After calculating the fuzzy weights of each element and hierarchy, the user can make a decision based on the significance and fuzzy weights revealed by the hierarchies and elements.

Green supplier performance evaluation stage: The PCB Company in this case study was evaluated and assessed the performances of three types of green suppliers (the suppliers of processing machine tools, the 
suppliers of raw materials and the suppliers of maintenance spare parts).

The VIKOR is a multi-objective decision method using the compromise concept to select projects. This method can improve the drawbacks of TOPSIS score calculation (Opricovic and Tzeng, 2007). The VIKOR method which was proposed by (Opricovic and Tzeng, 2007). was applied to understand and evaluate the performance of three types of green suppliers, the five scale was designed for evaluators to identify the performance of the supplier indicators of three types of green suppliers, respectively, the weight of supplier indicators derived by FAHP and the statistical results of five-scale forms were then input to the VIKOR process for analysis. The major calculation steps of the VIKOR are listed as below (Opricovic and Tzeng, 2007; Wu et al., 2009).

Determine the aspired level and worst level: This step determines the best and worst performance values obtainable among the various aspects (assessment criteria), thus serving as a basis for gap calculation. The equation is as follows:

Ideal Solution: $x_{j}={ }_{\max } x_{j}, I=1,2, \ldots, m$ being the aspired level of each criterion as established by the decision maker; non-Ideal Solution: $x_{j}^{-}=\min x_{i j}, I=$ $1,2, \ldots, \mathrm{m}$ being the worst level or tolerable level of each criterion as established by the decision maker, where $x_{j}$ is the ideal solution of aspect $\mathrm{j}$ and $\mathrm{x}$ is the non-ideal solution of aspect $\mathrm{j}$. If all of $\mathrm{x}$ are added up together to form the performance values of one person in the respective aspects, it is a dream combination, which means that the person has the best performance value in all aspects. On the contrary, if $x_{j}^{-}$are added up together, a worst combination is formed, signifying that the person has gained the worst performance value in all aspects.

Calculate the distances and comprehensive indices: This step is used to calculate ideal and non-ideal gaps corresponding to evaluations of the options; the results are added up to obtain a general indicator. Where $\mathrm{s}_{\mathrm{i}}$ is the normalized gap between ideal solutions or the aspired solutions of ith option when $p=1$. The formula is shown below: $R_{i}$ is the gap between the worst level and the aspired level of option $i$, which is the maximum normalized gap:

$$
\begin{aligned}
& d_{i}^{p}=\left\{\sum_{j=1}^{n} w_{j}^{p}\left(\frac{x_{j}^{*}-x_{i j}}{x_{j}^{*}-x_{j}^{-}}\right)^{p}\right\}^{1 / p} \\
& S_{i}=d_{i}^{p=1}=\sum_{j=1}^{n} w_{j}\left(\frac{x_{j}^{*}-x_{i j}}{x_{j}^{*}-x_{j}^{-}}\right) ; p=1
\end{aligned}
$$

$$
\mathrm{R}_{\mathrm{i}}=\max _{\mathrm{i}}\left\{\left(\frac{\mathrm{x}_{\mathrm{j}}^{*}-\mathrm{x}_{\mathrm{ij}}}{\mathrm{x}_{\mathrm{j}}^{*}-\mathrm{x}_{\mathrm{j}}^{-}}\right) \mid \mathrm{j}=1,2, \ldots, \mathrm{n}\right\}
$$

Calculate the comprehensive weights $\mathrm{Gi}$ for enabling to obtain and compare the distances of projects with those of desired level and worst level.

Sort all projects by their weights for managers to comparison and selection on making decisions. Additionally, the managers can set the parameter $v$. The larger $v(>0.5)$ means that Gi trends the majority rule (Opricovic and Tzeng, 2007; Wu et al., 2009). The following formula is applied to calculate the overall weights:

$$
\begin{aligned}
& \mathrm{G}_{\mathrm{i}}=\mathrm{v}\left[\left(\mathrm{S}_{\mathrm{i}}-\mathrm{S}^{*}\right) /\left(\mathrm{S}^{-}-\mathrm{S}^{*}\right)\right] \\
& +(1-\mathrm{v})\left[\left(\mathrm{R}_{\mathrm{i}}-\mathrm{R}^{*}\right) /\left(\mathrm{R}^{-}-\mathrm{R}^{*}\right)\right], \mathrm{v}=0.5
\end{aligned}
$$

Where:

$S^{*}=\min _{i} S_{i}, S^{-}=\max _{i} S_{i}$ and $R^{*}=\min _{i} R_{i}, R^{-}=\max _{i} R_{i}$

and $\mathrm{v}$ is a weight parameter. When parameter $\mathrm{v}$ is greater $(>0.5)$, it means that the degree of regret obtained by $\mathrm{G}_{\mathrm{i}}$ is higher and biased to the majority rule. The parameter is usually set to 0.5 .

After the VIKOR analysis process, the performances of three green suppliers were evaluated and the performances of green supplier indicators of three types were identified. The results of VIKOR process are analyzed and compared in the next stage.

Comparison and analysis stage: This stage analyzes and compares the achievement of green supplier indicators and the supplier performance of different green suppliers. Using these results, procurements can make decisions to improve their supplier performance.

\section{RESULTS}

The questionnaire objects in this study are mainly the famous companies of the PCB industries in Taiwan. The persons participating to fill those questionnaires were the employees of fruitful professional careers and experiences. A questionnaire based on FAHP was distributed to 30 managers and procurements responsible for supplier evaluation. The questionnaire data were arranged and analyzed by the FAHP for understanding the concerned critical factors and aspect weights, the descriptions and weights of green supplier indicators are shown in Table 1. 
Am. J. Applied Sci., 8 (3): 246-253, 2011

Table 1: Dimension weight and ranking of the green supplier indicators

\begin{tabular}{llll}
\hline $\begin{array}{l}\text { Dimension } \\
\text { weight }\end{array}$ & $\begin{array}{l}\text { Initial fuzzy } \\
\text { weight }\end{array}$ & $\begin{array}{l}\text { Weights of } \\
\text { defuzzification }\end{array}$ & $\begin{array}{l}\text { Overall } \\
\text { ranking }\end{array}$ \\
\hline Quality & $(0.2021,0.3194,0.4708)$ & 0.3114 & 1 \\
Technology capacity & $(0.1291,0.2090,0.3069)$ & 0.2024 & 3 \\
Contamination control & $(0.1440,0.2173,0.3374)$ & 0.2193 & 2 \\
Environment management & $(0.0993,0.1474,0.2337)$ & 0.1508 & 4 \\
Green competition & $(0.0771,0.1069,0.1860)$ & 0.1161 & 5 \\
\hline
\end{tabular}

Table 2: Overall weight and ranking of the green supplier indicators

\begin{tabular}{|c|c|c|c|c|c|}
\hline Dimension & $\begin{array}{l}\text { Green supplier } \\
\text { performance indicators }\end{array}$ & $\begin{array}{l}\text { Initial fuzzy } \\
\text { weights }\end{array}$ & $\begin{array}{l}\text { Initial weights of } \\
\text { defuzzification }\end{array}$ & $\begin{array}{l}\text { Comprehensive weights } \\
\text { of defuzzification }\end{array}$ & Ranking \\
\hline \multirow[t]{3}{*}{ Quality } & Quality-related verification & $(0.2865,0.4665,0.7545)$ & 0.4650 & 0.1448 & 1 \\
\hline & Quality control & $(0.1894,0.3084,0.5098)$ & 0.3108 & 0.0968 & 3 \\
\hline & $\begin{array}{l}\text { The reliability for dealing with } \\
\text { abnormal quality }\end{array}$ & $(0.1382,0.2251,0.3638)$ & 0.2242 & 0.0698 & 5 \\
\hline Technology & Technology Level & $(0.1739,0.3228,0.4744)$ & 0.2983 & 0.0604 & 6 \\
\hline \multirow[t]{3}{*}{ Capacity } & $\begin{array}{l}\text { The development, innovation } \\
\text { and patent capacities }\end{array}$ & $(0.1391,0.2601,0.4621)$ & 0.2300 & 0.0465 & 11 \\
\hline & $\begin{array}{l}\text { The capacities and stability of } \\
\text { manufacturing processes of }\end{array}$ & $(0.1681,0.2601,0.4621)$ & 0.2735 & 0.0554 & 7 \\
\hline & $\begin{array}{l}\text { suppliers the control } \\
\text { capacities of production } \\
\text { yield rate }\end{array}$ & $(0.1255,0.1790,0.3407)$ & 0.1982 & 0.0401 & 14 \\
\hline Contamination & Waste material processes & $(0.3166,0.5230,0.7917)$ & 0.5067 & 0.1111 & 2 \\
\hline \multirow[t]{2}{*}{ Control } & $\begin{array}{l}\text { The control of energy } \\
\text { consumption }\end{array}$ & $(0.1542,0.2468,0.3904)$ & 0.2458 & 0.0539 & 9 \\
\hline & $\begin{array}{l}\text { The control of using } \\
\text { hazardous materials }\end{array}$ & $(0.1577,0.2320,0.4090)$ & 0.2475 & 0.0543 & 8 \\
\hline Environment & $\begin{array}{l}\text { standing monitoring and } \\
\text { check complying with } \\
\text { the regulations }\end{array}$ & $(0.3336,0.5674,0.8682)$ & 0.5466 & 0.0824 & 4 \\
\hline \multirow[t]{2}{*}{ Management } & Inner control procedures & $(0.1667,0.2646,0.4435)$ & 0.2703 & 0.0407 & 12 \\
\hline & $\begin{array}{l}\text { The design of transportation } \\
\text { procedures of green } \\
\text { supply chain }\end{array}$ & $(0.1172,0.1680,0.3076)$ & 0.1831 & 0.0276 & 16 \\
\hline Green & Social responsibility & $(0.2517,0.4349,0.6564)$ & 0.4145 & 0.0481 & 10 \\
\hline \multirow[t]{2}{*}{ Competition } & $\begin{array}{l}\text { Enabling to change } \\
\text { products and procedures } \\
\text { for reducing the use of } \\
\text { natural resources }\end{array}$ & $(0.2126,0.3460,0.5622)$ & 0.3459 & 0.0402 & 13 \\
\hline & $\begin{array}{l}\text { Materials and components } \\
\text { which can reduce the } \\
\text { use of natural resources }\end{array}$ & $(0.1515,0.2191,0.4057)$ & 0.2396 & 0.0278 & 15 \\
\hline
\end{tabular}

Based on the result of Table 2, the most concerned aspects are orderly: quality (0.3114), contamination control (0.2193), technology capacity (0.2024), environment management $(0.1508)$ and green competition (0.1161), while the company in this case study evaluates and selects the green suppliers.

Moreover, from the Table 2, to the evaluation index part of green suppliers, the most important five indices are sequentially: quality-related verification (0.1448), water material processes $(0.1111)$, quality control (0.0968), standing monitoring and check complying with the regulations $(0.0824)$ and reliability for dealing with abnormal quality (0.0698). The less concerned items are respectively the design of transportation procedures of green supply chain (0.0276), the use of natural resources for the materials and components $(0.0278)$.

This research result appears that, from the viewpoints of manufacturers to evaluate the green suppliers, the more concerned items are the qualities of provided products and technology capacities. Also, the capacity of processing waste materials is emphasized for providing the manufacturers with the better environment-protection products and services. However, the design of supply chain of transportation procedures and the use of natural resources are inclined to the inner control, management and design of green suppliers themselves. That is why the manufacturers less concern the assessment index of those aspects. 
Am. J. Applied Sci., 8 (3): 246-253, 2011

Table 3: The average value of five-scale form of green suppliers

\begin{tabular}{|c|c|c|c|}
\hline \multirow[b]{2}{*}{ Green supplier performance indicators } & \multicolumn{3}{|l|}{ Green suppliers } \\
\hline & Equipment machine tools & Raw materials & Spare parts \\
\hline Quality-related verification & 3.4000 & 3.4667 & 3.1000 \\
\hline Quality control & 3.6667 & 3.5667 & 3.1667 \\
\hline $\begin{array}{l}\text { The reliability for dealing } \\
\text { with abnormal quality }\end{array}$ & 3.6000 & 3.5000 & 3.1000 \\
\hline Technology Level & 3.3333 & 3.3000 & 2.9000 \\
\hline $\begin{array}{l}\text { The development, innovation } \\
\text { and patent capacities }\end{array}$ & 3.1333 & 3.2000 & 2.8000 \\
\hline $\begin{array}{l}\text { The capacities and stability of } \\
\text { manufacturing processes of suppliers }\end{array}$ & 3.6667 & 3.4333 & 2.9667 \\
\hline $\begin{array}{l}\text { The control capacities of production } \\
\text { yield rate }\end{array}$ & 3.7000 & 3.4667 & 2.9333 \\
\hline Waste material processes & 3.4667 & 3.3667 & 3.1000 \\
\hline The control of energy consumption & 3.4000 & 3.4667 & 3.0667 \\
\hline The control of using hazardous materials & 3.4667 & 3.6667 & 3.2333 \\
\hline $\begin{array}{l}\text { standing monitoring and check } \\
\text { complying with the regulations }\end{array}$ & 3.3000 & 3.4000 & 2.8333 \\
\hline Inner control procedures & 3.2667 & 3.4000 & 2.8667 \\
\hline $\begin{array}{l}\text { The design of transportation procedures } \\
\text { of green supply chain }\end{array}$ & 3.2333 & 3.2667 & 2.8667 \\
\hline Social responsibility & 3.4667 & 3.3667 & 3.1000 \\
\hline $\begin{array}{l}\text { Enabling to change products and } \\
\text { procedures for reducing the use } \\
\text { of natural resources }\end{array}$ & 3.4667 & 3.5667 & 3.2000 \\
\hline $\begin{array}{l}\text { Materials and components which } \\
\text { can reduce the use of natural resources }\end{array}$ & 3.4667 & 3.6000 & 3.1667 \\
\hline
\end{tabular}

Table 4: The values of Si and Ri of the green suppliers

\begin{tabular}{llll}
\hline Green suppliers & Equipment machine tools & Raw materials & Spare parts \\
\hline $\mathbf{S}_{\mathbf{j}}$ & 0.3873 & 0.3892 & 0.4901 \\
$\mathrm{R}_{\mathrm{j}}$ & 0.0579 & 0.0555 & 0.0688 \\
\hline
\end{tabular}

Table 5: The Gi of the green suppliers $(\mathrm{v}=0.5)$

\begin{tabular}{llll}
\hline Green suppliers & Equipment machine tools & Raw materials & Spare parts \\
\hline $\mathrm{G}_{\mathrm{j}}$ & 0.3936 & 0.3862 & 0.4826 \\
\hline
\end{tabular}

In the aspect of green suppliers, the general manufacturers have to confront three types of green suppliers which are respectively the suppliers of equipment machine tools, the suppliers of raw materials and the suppliers of spare parts. Confronting the green environment-protection agitations, the manufacturers should properly assess and compare the achievement performances on the green environment-protection of those three types of suppliers. Consequently, the final products from the manufacturers can meet with the obligated green requirements for environment protection. In this study, the 16 indices assessed by the FAHP are used to assess all suppliers of the equipment machine tools, the raw materials and the spare parts.

There is setup a 5-point scale for assessing all rules, each of which represents the different satisfactions, including point 1 of extremely low satisfaction, point 2 of low satisfaction, point 3 of fair satisfaction, point 4 of high satisfaction and point 5 of extremely high satisfaction. There asked totally 30 employees from the companies in this case study from the PCB industries to finish the assessments for constructing the comprehensive assessment on evaluating the suppliers of the equipment machine tools, the raw materials and the spare parts as indicated in the Table 3. In addition, through employing the comprehensive weights calculated by the FAHP and the VIKOR, the suppliers of the equipment machine tools, the raw materials and the spare parts were assessed and sorted. Initially, in this study, the aspired level $x *$ is determined by 5 and the worst level $\mathrm{x}$ - is set as 1 . Combining with the fuzzy weights of the FAHP to conduct the calculations, the decision mode is optimized if it is even closer to 0 ; the project effect is better (Opricovic and Tzeng, 2007; Wu et al. 2009). Analyzed by the VIKOR and calculated by $\mathrm{v}=0.5$, the calculating results are listed in the Table 4-5. The values of $\mathrm{Si}$ and $\mathrm{Ri}$ from the green suppliers are shown in Table 4. The values of Gi from the green suppliers are shown in Table 5. 


\section{DISCUSSION}

The research results, which the company in this case study assessed at the suppliers of the equipment machine tools, the raw materials and the spare parts, show that the satisfaction of the suppliers of raw materials (0.3862) is superior to the suppliers of equipment machine tools (0.3936) and even better than that of the suppliers of spare parts (0.4826). That means the company in this case study can still accept the green products and services provided by their suppliers of the raw materials and equipment machine tools. Under the above comparisons, the suppliers of spare parts should be improved. That company should greatly concern the products and service levels provided by her suppliers of the spare parts for expectedly agreeing with the standards of related environment-protection regulations.

\section{CONCLUSION}

For quickly improving the product qualities, the enterprises require them shortly to meet with the requirements of the EU's criterions. In accordance with the literature arrangements, this study constructs a set of necessary indices suitable for the PCB manufacturers to evaluate the green suppliers. Also, the FAHP is used to explore the significances between those indices and conduct a sorting sequence. Finally, use the VIKOR to assess at the satisfaction that the manufacturers evaluate the suppliers of processing equipment machine tools, the raw materials and the maintenance spare part.

Through the previous research results, the most concerned aspect found by the FAHP is the quality when the company in this study case evaluates the green suppliers. The next are the contamination control and the technology capacity. To the index part, the most five indices are in turn: Quality-related verifications, waste material processes, quality control, standing monitoring and check complying with the regulations and reliability for dealing with abnormal quality.

In the analyses by the VIKOR, the company is this case study is slightly more satisfied with the products and services provided by the suppliers of the raw materials and the processing equipment. The main reason may be that the PCB manufacturers even more emphasize the sources of raw materials and processing procedures. Furthermore, it is continuously concerned and requested that the suppliers of the processing equipment and the raw materials should conform to the requirements of environment protection. Secondly, perhaps because of fewer frequencies for maintaining and exchanging parts, that causes the suppliers of the maintenance spare parts are less concerned and requested.
On the basis of above inferences, the company in this case study should pay more attention to the products and service level provided by the suppliers of the spare parts for expectedly reaching the criterions setup by the related environment-protection regulations. Furthermore, the contributions by this study will be able to provide the PCB manufacturers with the reference bases to conduct the procurements for green processes.

\section{REFERENCES}

Ahmed, E.F., W.J. Yang and M.Y. Abdullah, 2009. Novel method of the combination of forecasts based on rough sets. J. Comput. Sci., 5: 440-444. DOI: $10.3844 /$ jessp. 2009.440 .444

Athanasios, V., A. Stergios and E.C. Laskaridou, 2010. The importance of information through accounting practice in agricultural sector-european data network. J. Soc. Sci., 6: 221-228. DOI: 10.3844/jssp.2010.221.228

Bovornsethanant, S. and S. Wongwises, 2010. Assessment of useful life of lubricants using Analytical Hierarchy Process (AHP) and Vector Projection Approach (VPA). Am. J. Eng. Applied Sci., 3: 470-475. 0.3844/ajeassp. 2010.470 .475

Buckley, J.J., 1985. Fuzzy hierarchical analysis. Fuzzy Set Syst., 17: 233-247. DOI: 10.1016/01650114(85)90090-9

Cheong, C.W., L.H. Jie, M.C. Meng and A.L.H. Lan, 2008. Design and development of decision making system using fuzzy analytic hierarchy process. Am. J. Applied Sci., 5: 783-787. DOI: 10.3844/ajassp.2008.783.787

Daut, I., R. Ali and S. Taib, 2006. Design of a singlephase rectifier with improved power factor and low THD using boost converter technique. Am. J. Applied Sci., 3: 2025-2028. DOI: 10.3844/ajassp.2006.2025.2028

Gheidar, K.J., S.H. Ghodsypour and C.O. Brien, 2009. Optimizing whole supply chain benefit versus buyer's benefit through supplier selection. Int. J. Prod. $\quad$ Econ., 121: 482-493. DOI:10.1016/j.jppe.2007.04.009.

Hoffmann, K. and J. Hoffmann, 2007. The utilization of peat, lignite and industrial wastes in the production of mineral-organic fertilizers. Am. J. Agric. Biol. Sci., 2: 254-259. $\quad$ DOI: 10.3844/ajabssp.2007.254.259

Kumar, K., J. Singh and P. Kumar, 2009. Fuzzy reliability and fuzzy availability of the serial process in butter-oil processing plant. J. Math. Statis., 5: 65-71. DOI: 10.3844/jmssp.2009.65.71 
Kuo, R.J., Y.C. Wang and F.C. Tien, 2010. Integration of artificial neural network and MADA methods for green supplier selection. J. Clean Prod., 18: 1161-1170. DOI:10.1016/j.jclepro.2010.03.020.

Lee, A.H.I., H.Y. Kang, C.F. Hsu and H.C. Hung, 2009. A green supplier selection model for high-tech industry. Expert Syst. Appl., 36: 7917-7927. DOI:10.1016/j.eswa.2008.11.052

Liu, C.C., 2005. A study for allocating resources to research and development programs by integrated subjective and objective decision method. Am. J. Applied Sci., 2: 976-979. DOI: 10.3844/ajassp.2005.976.979

Lotfi, S., K. Habibi and M.J. Koohsari, 2009. An analysis of urban land development using multicriteria decision model and geographical information system (a case study of babolsar city). Am. J. Applied Sci., 5: 87-93. DOI: 10.3844/ajessp.2009.87.93

Misran, N., M.T. Islam and N.K. Jiunn, 2008. Design and development of broadband inverted E-shaped patch microstrip array antenna for $3 \mathrm{G}$ wireless network. Am. J. Applied Sci., 5: 427-434. DOI: 10.3844/ajassp.2008.427.434

Nader, N. and F. Mehdizadeh, 2010. Utilization of specific index for measuring the association between periodontal conditions and coronary artery disease. Current Res. Dentistry, 1: 1-5. DOI: 10.3844/crdsp.2010.1.5

Opricovic, S. and G.H. Tzeng, 2007. Extended VIKOR method in comparison with outranking methods. Eur. J. Oper. Res., 178: 514-529. DOI:10.1016/j.ejor.2006.01.020
Opricovic, S. and G.H. Tzeng,, 2003. Defuzzification within a multicriteria decision model. Int. J. Uncertain Fuzz., 11: 635-652. DOI: $10.1142 / \mathrm{S} 0218488503002387$

Punniyamoorthy, M., P. Mathiyalagan and P. Parthiban, 2011. A strategic model using structural equation modeling and fuzzy logic in supplier selection. Expert Syst. Appl., 38: 458-474. DOI: 10.1016/j.eswa.2010.06.086

Rahmat, M.F., M.D. Isa, K. Jusoff, T.A. Hussin and S.M. Rozali, 2010. Image reconstruction algorithm for electrical charge tomography system. Am. J. Applied Sci., 7: 1254-1263. DOI: 10.3844/ajassp.2010.1254.1263

Sun, C.C., T.R.G. Lin and W.H. Tzeng, 2009. The evaluation of cluster policy by fuzzy MCDM: Empirical evidence from HsinChu Science Park. Expert Syst. Appl., 36: 11895-11906. DOI: 10.1016/j.eswa.2009.04.019

Wu, H.Y., G.H. Tzeng and Y.H. Chen, 2009. A fuzzy MCDM approach for evaluating banking performance based on Balanced Scorecard. Expert Syst. Appl., 36: 10135-10147. DOI: 10.1016/j.eswa.2009.01.005

Xinxing, L., W. Chong, D. Rosenberg and D. Barnes, 2009. Supplier selection in agile supply chains: An information-processing model and an illustration. J. pur. Supply Manage., 15: 249-262. DOI: 10.1016/j.pursup.2009.05.004 